\title{
Pengaruh Penerapan Metode Pembelajaran Socrates Terhadap Kemampuan Berpikir Kreatif Matematis Siswa Kelas VIII MTs Negeri 2 Bombana
}

\author{
(The Effect Of Application Of Socrates Learning Methods On Student Creative Thinking \\ Ability Class VIII Mts Negeri 2 Bombana)
}

\author{
Siska Damayanti Syukur ${ }^{1}$, Kadir $^{2}$, Anwar Bey ${ }^{2}$ Rahmad Prajono ${ }^{3}$ \\ ${ }^{1}$ Alumnus Jurusan Pendidikan Matematika FKIP Universitas Halu Oleo; Co-author: \\ siskadamayanti.syukur@gmail.com \\ ${ }^{2}$ Dosen Pendidikan Matematika FKIP dan PPS Universitas Halu Oleo \\ ${ }^{3}$ Dosen Pendidikan Matematika FKIP Universitas Halu Oleo
}

\begin{abstract}
Abstrak: Penelitian ini bertujuan untuk mengetahui: 1)aktivitas guru dan siswa selama pembelajaran dengan metode pembelajaran Socrates, 2) gambaran kemampuan berpikir kreatif matematis siswa sebelum dan setelah pembelajaran dengan menggunakan metode pembelajaran Socrates 3) pengaruh metode pembelajaran Socrates terhadap kemampuan berpikir kreatif matematis siswa. Populasi dalam penelitian ini adalah seluruh siswa kelasVIII MTs Negeri 2 Bombana yang tersebar pada lima kelas paralel, dengan jumlah siswa sebanyak 180 orang. Teknik pengambilan sampel dalam penelitian ini menggunakan teknik Purposive Sampling. Teknik pengumpulan data dilakukan dengan pemberian tes kemampuan berpikir kreatif. Teknik analisis data menggunakan statistik deskriptif dan statistik inferensial. Hasil penelitian ini menunjukkan bahwa: kemampuan berpikir kreatif matematis siswa sebelum diajar menggunakan metode pembelajaran Socrates diperoleh bahwa kemampuan berpikir kreatif matematis siswa pada pretest bernilai rata-rata sebesar 27,02 sedangkan kemampuan berpiki kreatif matematis siswa pada posttest diperoleh nilai rata-rata sebesar 63,80. Varians pada saat pretest adalah sebesar 170,389 dan varians pada saat posttest adalah sebesar 295,003. Hasil tersebut menunjukkan bahwa kemampuan berpikir kreatif matematis siswa kelas VIII MTs Negeri 2 Bombana mengalami peningkatan atau lebih baik setelah diajar dengan menggunakan metode pembelajaran Socrates.
\end{abstract}

Kata kunci: Metode Pembelajaran Socrates, Kemampuan Berpikir Kreatif Matematis.

\begin{abstract}
This study aims to find out: 1)teacher and student activities during learning with Socrates learning methods, 2)description of students 'mathematical creative thinking skills before and after learning using Socrates learning methods 3)the influence of Socrates's learning methods on students' creative mathematical thinking abilities. The population in this study were all students of class VIII MTs Negeri 2 Bombana spread over five parallel classes, with the number of students as many as 180 people. The sampling technique in this study used Purposive Sampling techniques. Data collection techniques are carried out by giving a test of creative thinking ability. Data analysis techniques use descriptive statistics and inferential statistics. The results of this study indicate that: mathematical creative thinking skills of students before being taught using the Socrates learning method found that students' mathematical creative thinking skills at pretest were valued at an average of 27.02 while the mathematical creative ability of students in the posttest obtained an average value of 63,80. Variances at the pretest are 170,389 and the variance at posttest is 295,003 . These results indicate that the mathematical creative thinking ability of class VIII students of MTs Negeri 2 Bombana has improved or improved after being taught using the Socrates learning method
\end{abstract}

Keywords: Socrates Learning Method, Mathematical Creative Thinking Ability

\section{PENDAHULUAN}

Zaman semakin berkembang, kemajuan ilmu pengetahuan dan teknologi sangat cepat sehingga diperlukan kemampuan yang kritis, sistematis, logis, dan kreatif. Matematika merupakan salah satu mata pelajaran yang berperan untuk mempersiapkan siswa agar sanggup menghadapi perubahan keadaan atau tantangan-tantangan di dalam kehidupan dan di dunia yang selalu berkembang 
melalui latihan membuat keputusan dan kesimpulan atas dasar pemikiran secara logis, rasional, kritis, cermat, jujur, efisien, dan efektif. Pembelajaran matematika diarahkan agar siswa dapat menggunakan matematika dan cara berpikir matematika dalam kehidupan sehari-hari, dan dalam mempelajari berbagai ilmu pengetahuan.

Kemampuan berpikir kreatif siswa yang memadai berperan penting dalam proses pembentukan karakter siswa, oleh sebab itu kualitas dari sistem pendidikan itu sendiri sangat diperlukan untuk membangun kreativitas dan kemandirian siswa dalam menentukan pilihan hidup dimasa depan. Proses pembelajaran pada satuan pendidikan seharusnya diselenggarakan secara interaktif, inspiratif, menyenangkan, menantang, dan memotivasi siswa untuk berpartisipasi aktif, serta memberikan ruang yang cukup bagi prakarsa kreativitas dan kemandirian sesuai dengan bakat, minat dan perkembangan fisik serta psikologis peserta didik. Berpikir kreatif merupakan salah satu keterampilan yang penting bagi setiap siswa dalam menyelesaikan suatu masalah sehingga dapat membuat keputusan yang tepat atas informasi yang didapatkan. Secara sederhana, berpikir adalah memproses informasi secara mental atau secara kognitif. Secara lebih formal, berpikir adalah penyusunan ulang atau manipulasi kognitif baik informasi dari lingkungan maupun simbol-simbol yang disimpan dalam long term memory.

$$
\text { Khodijah (2006: }
$$

mengemukakan berpikir adalah sebuah representasi simbol dari beberapa peristiwa atau item. Setiap kegiatan jiwa yang menggunakan kata-kata dan pengertian selalu mengandung hal berpikir oleh sebab itu berpikir tidak dapat didefenisikan dalam arti terbatas. Misalnya berpikir untuk menemukan pemahaman atau pengertian yang kita kehendaki. Berpikir memiliki beberapa tahapan, salahsatunya kemampuan berpikir kreatif. Kemampuan berpikir kreatif adalah kemampuan untuk menghasilkan ide atau gagasan yang baru dalam menghasilkan suatu cara dalam menyelaikan masalah, bahkan menghasilkan cara yang baru sebagai solusi alternatif (Lestari, 2017: 23). Adapun ciri-ciri kemampuan berpikir kreatif menurut Hidayat (2011: 274), berpikir kreatif matematis adalah kemampuan yang meliputi keaslian, kelancaran, kelenturan, dan keterperincian respon siswa dalam menggunakan konsep matematika.

Metode Socrates (Socrates Method), yaitu suatu cara menyajikan bahan/materi pelajaran, dimana anak didik/siswa dihadapkan dengan suatu deretan pertanyaan-pertanyaan, yang dari serangkaian pertanyaan-pertanyaan itu diharapkan siswa mampu menemukan jawabannya, atas dasar kecerdasannya dan kemampuannya sendiri.

Metode pembelajaran Socrates (Socrates Method) merupakan suatu metode pembelajaran yang dilakukan oleh dua orang atau lebih yang saling berdiskusi dan dihadapkan dengan suatu deretan pertanyaan-pertanyaan, yang dari serangkaian pertanyaan-pertanyaan itu diharapkan siswa mampu menemukan jawabannya, saling membantu dan menemukan sebuah jawaban dari pertanyaan-pertanyaan yang sulit, (Hatta dalam Pahlavi, 2013: 7) misalnya dalam pembelajaran dengan materi Fungsi, guru mengajukan pertanyaan umpan seperti "apa itu fungsi?" lalu siswa akan mulai berdiskusi dan mengeluarkan pendapat mereka mengenai pengertian fungsi. Setelah menemukan jawaban yang tepat guru kembali mengajukan pertanyaan umpan seperti sebelumnya.

Metode pembelajaran Socrates bukanlah dengan cara menjelaskan, melainkan dengan cara mengajukan pertanyaan, menunjukkan kesalahan 
logika dari jawaban, serta dengan menanyakan lebih jauh lagi, sehingga para siswanya terlatih untuk mampu memperjelas ide-ide mereka sendiri dan dapat mendefenisikan konsep-konsep yang mereka maksud dengan mendetail.

Metode Pembelajaran Socrates memudahkan siswa mendapatkan pemahaman secara berangkai dari bentuk tanya jawab yang dilakukan. Menurut Johnson (2002: 194) prosedur dalam Metode Pembelajaran Socrates adalah sebagai berikut: (1) Menyiapkan deretan pertanyaan-pertanyaan yang akan diajukan kepada siswa, dengan memberi tanda atau kode-kode tertentu yang diperlukan. (2) Guru mengajukan pertanyaan-pertanyaan kepada siswa dan siswa diharapkan dapat menemukan jawaban jawaban yang benar. (3) Ajarkan mengapa pengetahuan itu penting dan bagaiman pengetahuan itu dapat diterapkan untuk memecahkan masalah. (4) Tuntun eksplorasi siswa. Dalam proses pemecahan masalah guru berperan untuk (a) Membiarkan eksplorasi siswa tak terintangi dan partisipasi aktif, (b) Membantu siswa dalam menghubungkan pengetahuan baru dan pengetahuan terdahulu, (c) Membantu siswa membentuk dan menghayati masalah atau tugas, (d) Membantu siswa mengidentifikasi persamaan antara masalah baru dan pengalaman yang lalu yang berisikan masalah serupa. (5) Memberikan umpan balik mengenai benar atau salahnya jalan pikiran dan jalur pemecahan masalah. Penekanan teknik bertanya dengan Metode Pembelajaran Socrates adalah penjelasan konsep-konsep dan gagasan-gagasan melalui penggunaan pertanyaan-pertanyaan pancingan. Sebagai suatu teknik pembelajaran, ia harus dipikirkan dan ditatar dengan baik. (6) Pertanyaan yang diajukan itu dijawab dengan oleh siswa, maka guru dapat melanjutkan atau mengalihkan pertanyaan berikutnya hingga semua soal selesai terjawab oleh siswa. (7) Jika pada setiap soal pertanyaan yang diajukan ternyata belum memenuhi tujuan, maka guru hendaknya mengulangi kembali pertanyaan tersebut. Dengan cara memberikan sedikit ilustrasi, apersepsi dan sekedar meningkatkan dan memudahkan berpikir siswa, dalam menemukan jawaban yang tepat dan cermat.

Penelitian yang relevan dengan penelitian ini adalah

1 Penelitian Pahlavi (2013) menunjukkan bahwa kemampuan berpikir kritis siswa yang diajar menggunakan metode Socrates lebih baik daripada siswa yang diajar dengan metode konevensional, hal ini ditunjukkan dengan rata-rata nilai siswa dikelas eksperimen lebih besar dibanding rata-rata nilai siswa dikelas kontrol.

2 Penelitian Andika (2013). Diperoleh kesimpulan bahwa, secara umum siswa yang aktif saat pembelajaran menggunakan metode pembelajaran Socrates Kontekstual menunjukkan hasil yang cenderung lebih baik daripada siswa yang kurang aktif.

3 Penelitian Arifin, Sugeng, dan Tina (2014) diperoleh kesimpulan bahwa penerapan metode Socrates dengan pendekatan kontekstual berjalan cukup baik ditinjau dari proses dan kemampuan berpikir kritis siswa.

Berdasarkan ciri-ciri dari aspek kemampuan berpikir kreatif maka setiap aspek dapat dikembangkan menjadi beberapa indikator tertentu. Penjabaran aspek-aspek kemampuan berpikir kreatif yakni keterampilan berpikir lancar mencakup dua indikator yaitu menjawab dengan sejumlah jawaban jika ada pertanyaan dan mempunyai banyak gagasan mengenai suatu masalah. Berpikir luwes juga mencakup dua indikator penting yakni memberikan macam-macam penafsiran (interpretasi) terhadap suatu gambar, cerita, atau masalah dan menggolongkan hal-hal menurut pembagian (kategori) yang berbedabeda.Adapun indikator dari keterampilan berpikir orisinal yakni setelah membaca 
atau mendengar gagasan-gagasan, bekerja untuk menemukan penyelesaian yang baru. Indikator dari keterampilan merinci atau elaborasi yakni mencari arti yang lebih mendalam terhadap jawaban atau pemecahan masalah dengan melakukan langkah-langkah terperinci (Hawadi, $d k k$ dalam Laksmi, 2012: 8).

Pendidikan menjelaskan bahwa sistem pendidikan yang baik adalah sistem pendidikan yang tetap memberikan ruang bagi pengembangan kreativitas anak. Namun dari hasil obvservasi awal peneliti kondisi ini belum terlihat pada pendidikan di MTs Negeri 2 Bombana.

Hasil pengamatan peneliti di MTs Negeri 2 Bombana, menunjukkan bahwa kemampuan berpikir kreatif siswa masih kurang dalam pembelajaran matematika khususnya dalam keluwesan menjawab soal-soal matematika. Siswa masih dinilai pasif dalam pembelajaran khususnya matematika serta jawaban yang mereka berikan hanya berdasarkan pada apa yang diajarkan guru dan tertera pada buku teks. Siswa masih terpaku pada cara yang tertulis didalam buku teks dan belum mengembangkan pemikirannya untuk menyelesaikan soal-soal matematika dengan cara lain atau cara siswa itu sendiri.

Hasil diskusi dengan guru mata pelajaran matematika diperoleh bahwa 50 persen siswa masih kesulitan dalam menjawab soal secara kreatif. Setiap kali guru selesai menjelaskan dan member soal latihan, siswa dengan mudah menjawab. Namun ketika soal diubah dalam bentuk lain, siswa langsung mengalami kesulitan dalam menyelesaikannya.

Hasil observasi peneliti menunjukkan bahwa, masalah ini disebabkan oleh beberapa hal seperti kurang beragamnya soal dan cara menyelesaikannya, soal yang dilatihkan dan penyelesaiannya kurang jelas, serta kurang terciptanya suasana tanya jawab yang dapat membimbing siswa dalam memperoleh cara menyelesaikan suatu soal matematika. Oleh karena itu, perlu adanya metode pembelajaran yang inovatif, untuk lebih member kesempatan kepada siswa untuk mengembangkan kemampuan berpikirnya terutama dalam hal kemampuan berpikir kreatif sehingga menciptakan tanya jawab terbimbing ketika dilatihkan soal-soal yang beragam.

Alternatif pengajaran yang dapat digunakan untuk mengatasi permasalahan tersebut adalah Metode Pembelajaran Socrates. Metode Pembelajaran Socrates merupakan salahsatu metode tanya jawab yang sangat bagus digunakan untuk membimbing dan memperdalam tingkat pemahaman yang berkaitan dengan materi yang diajarkan, sehingga peserta didik mendapatkan pemikirannya sendiri dari hasil konflik kognitif yang terpecahkan (Johnson, 2002: 194).

\section{METODE PENELITIAN}

Populasi dalam penelitian ini adalah seluruh siswa kelas VIII di MTs Negeri 2 Bombana pada tahun ajaran 2018/2019

yang tersebar pada 5 kelas paralel, yaitu kelas $\mathrm{VIII}_{\mathrm{A}}$ sampai kelas $\mathrm{VIII}_{\mathrm{E}}$ dengan jumlah siswa sebanyak 180 siswa.

\section{Tabel 1. Populasi Penelitian}

\begin{tabular}{llllll}
\hline \multicolumn{1}{c}{ Kelas } & \multicolumn{5}{c}{ VIII } \\
& \multicolumn{1}{c}{$\mathbf{A}$} & \multicolumn{1}{c}{ B } & \multicolumn{1}{c}{$\mathbf{C}$} & \multicolumn{1}{c}{$\mathbf{D}$} & \multicolumn{1}{c}{$\mathbf{E}$} \\
\hline Jumlah Siswa & 38 & 35 & 37 & 36 & 34 \\
Rata-rata & 80,11 & 80,88 & 79,05 & 80,36 & 79,74 \\
Varians & 5,99 & 5,93 & 4,81 & 4,73 & 3,55 \\
\hline
\end{tabular}


Penentuan sampel dalam penelitian ini dilakukan dengan menggunakan teknik purposive sampling yaitu pengambilan sampel dengan teknik pertimbangan. Pemilihan sampel ini didasari pada pertimbangan bahwa diambil kelas yang memiliki kemampuan dengan varians paling kecil,sehingga diperoleh kelas VIII $_{\mathrm{E}}$

\section{Tabel 2. Desain Penelitian One Group Pretest Posttest Design}

\begin{tabular}{lcl}
\hline Pretes & Treatment & Posttest \\
\hline $\mathrm{O}_{1}$ & $\mathrm{X}$ & $\mathrm{O}_{2}$ \\
\hline
\end{tabular}

Keterangan :

$\mathrm{O}_{1}=$ tes awal (pretest) sebelum menerapkan metode pembelajaran Socrates

$\mathrm{O}_{2}=$ tes akhir (posttest) setelah menerapkan metode pembelajaran Socrates

$\mathrm{X}=$ perlakuan terhadap kelas eksperimen yaitu dengan menerapkan metode pembelajaran Socrates

Skor hasil tes kemampuan berpikir kreatif matematis siswa dikonversi ke skala 100 dengan aturan.

$$
\text { Nilai Siswa }=\frac{\text { skorperole han }}{\text { skormaksimal }} \times 100
$$

Uji panelis berupa uji keterbacaan butir soal terlebih dahulu dilakukan sebelum instrumen penelitian digunakan. Hasil uji panelis tersebut kemudian dianalisis validitas dan reliabilitasnya

Analisis validitas penilaian panelis digunakan untuk mengetahui validitas konsep instrumen melalui penilaian panelis dengan menggunakan rumus:

$$
V=\frac{\sum n_{i}\left|i-l_{o}\right|}{[N(c-1)]}
$$

(Aiken dalam Bandi, 2015: 29).

Di mana:

$V=$ Indeks validitas isi

$n_{i}=$ Cacah dari titik skala hasil penilaian rater

$i=$ Titik skala ke-I $(\mathrm{I}=1,2,3,4,5)$

$l_{o}=$ Titik skala terendah
Penelitian ini menggunakan desain penelitian One Group Pretest Posttest Design, yaitu penelitian yang dilaksanakan pada satu kelompok saja tanpa ada kelompok pembanding. Berikut ini merupakan tabel desain penelitian one group pretest posttest design.

$N=$ Jumlah rater $\left(\Sigma \mathrm{n}_{\mathrm{i}}\right)$

$c=$ Banyaknya titik skala

Nilai $\mathrm{V}$ terletak antara 0 dan 1 (valid $\geq$ $0,6)$.

Reliabilitas menunjukkan pada suatu pengertian bahwa suatu instrumen cukup dapat dipercaya untuk digunakan sebagai alat pengumpul data. Untuk mengetahui reliabilitas tes uraian digunakan rumus Alpha Cronbach. Untuk menentukan tinggi rendahnya reliabilitas sebuah tes menggunakan ketentuan sebagai berikut:

- $0 \leq r_{\alpha} \leq 0,20 \quad$ Tingkat reliabilitas tes sangat rendah,

- $0,20<r_{\alpha} \leq 0,40$ Tingkat reliabilitas tes rendah,

- $0,40<r_{\alpha} \leq 0,60$ Tingkat reliabilitas tes sedang,

- $0,60<r_{\alpha} \leq 0,80$ Tingkat reliabilitas tes tinggi,

- $0,80<r_{\alpha} \leq 1,00$ Tingkat reliabilitas tes sangat tinggi.

Suatu soal dapat digunakan sebagai alat ukur kemampuan berpikir kreatif matematis apabila: (1) telah diuji panelis dan valid., (2) Reliabilitasnya $0,60<r_{\alpha}$ dengan tingkat reliabilitas tes tinggi.

Teknik pengumpulan data dalam penelitian ini dilakukan dengan pemberian tes awal kemampuan berpikir kreatif matematis siswa berbentuk tes uraian.Observasi dilakukan pada setiap pertemuan yaitu sebanyak empat kali pertemuan. Hasilnya dipergunakan untuk memperoleh data tentang aktivitas 
kemampuan selama mengikuti pembelajaran dengan menggunakan metode pembelajaran Socrates.

Pemberian tes keampuan berpikir kreatif matematis siswa dilakukan sebanyak dua kali, yaitu pada awal pembelajaran sebelum diberi perlakuan (pretest) dan pada akhir pembelajaran setelah diberi perlakuan (posttest).

Analisis deskriptif diperlukan untuk mendeskripsikan atau menggambarkan data penelitian kemampuan berpikir kreatif matematis siswa yakni nilai pretest dan posttest yang diperolehpada kelas eksperimen tanpa bermaksud membuat kesimpulan yang berlaku untuk populasi. Statistik deskriptif dalam penelitian ini antara lain adalah penyajian data melalui tabel dan grafik, pengukuran tendensi sentral (penghitungan mean, median, dan modus), penghitungan varians, standar deviasi, nilai maksimum dan nilai minimum.

Teknik analisis data dengan statistik inferensial dilakukan untuk keperluan pengujian hipotesis penelitian.Sebelum pengujian hipotesis dilakukan terlebih dahulu dilakukan pengujian prasyarat yaitu uji normalitas.

Uji normalitas dimaksudkan untuk mengetahui apakah data yang diteliti berasal dari populasi yang berdistribusi normal atau tidak.Untuk keperluan ini, maka uji statistik yang digunakan adalah Uji Kolmogorov-Smirnov dengan bantuan SPSS.Secara statistik hipotesis dapat dirumuskan.

$\mathrm{H}_{0}$ : data berdistribusi normal

$\mathrm{H}_{1}$ : data tidak berdistribusi normal

Dengan kriteria pengambilan keputusan, yaitu:

\section{HASIL PENELITIAN}

Data diperoleh berdasarkan daftar aktivitas guru yang tertera pada lembar observasi yang ada pada tiap pembelajaran a) Terima $\mathrm{H}_{0}$ jika nilai Asymp. Sig (2tailed) $>\alpha=0,05$

b) Tolak $\mathrm{H}_{0}$ jika nilai Asymp. Sig (2tailed) $\leq \alpha=0,05$

Untuk mengetahui lebih lanjut pengaruh pemberian perlakukan berupa metode pembelajaran Socrates (X) terhadap kemampuan berpikir kreatif matematis siswa (Y) maka dilakukan pengujian hipotesis.Uji hipotesis dengan uji-t sampel berpasangan (Paired Sample t-test).Data yang diolah dalam uji-t ini menggunakan data pretest dan posttest. Uji hipotesis dengan uji-t hanya dilakukan jika data berdistribusi normal.Rumus uji-t yang digunakan adalah.

$$
t=\frac{\overline{\mathrm{B}}}{\frac{\mathrm{S}_{\mathrm{B}}}{\sqrt{n}}}
$$

(Sudjana, 2005: 242)

Dengan:

$\mathrm{t}=$ nilai hitung Uji- $\mathrm{t}$

$\overline{\mathrm{B}} \quad=$ rata-rata selisih pretest dan posttest

$S_{\mathrm{B}} \quad=$ standar deviasi selisih pretest dan posttest

$\mathrm{n} \quad=$ jumlah sampel

Dengan kriteria pengujian yaitu terima $\mathrm{H}_{0}$ jika $t_{1-\alpha}>t_{\text {hitung dimana }}$ $t_{1-\propto}$ didapat dari daftar distribusi t dengan peluang $(1-\alpha)$ dan $d k=(n-1)$. Dalam hal lainnya, $\mathrm{H}_{0}$ ditolak.

Uji-t satu sampel berpasangan dapat pula dilakukan dengan bantuan SPSS dengan kriteria pengambilan keputusan yaitu:

1) Jika setengah nilai setengah Sig.(2tailed) $\geq \alpha=0,05$, maka terima $\mathrm{H}_{0}$.

2) Jika setengah nilai setengah Sig.(2tailed) $<\alpha=0,05$, maka tolak $\mathrm{H}_{0}$.

menggunakan metode pembelajaran Socrates dan terdiri dari lima kali pertemuan, yang disajikan dalam tabel 2 . 
Tabel 3. Hasil Observasi Aktivitas Guru

\begin{tabular}{ccc}
\hline Pertemuan & Skor Total & Presentase (\%) \\
\hline 1 & 25 & 86,21 \\
2 & 27 & 93,10 \\
3 & 28 & 96,56 \\
4 & 29 & 100,00 \\
\hline
\end{tabular}

Berdasarkan tabel 3 persentase keberhasilan pengelolaan pembelajaran pada pertemuan pertama mencapai 86,21 persen. Persentase keberhasilan pengelolaan pembelajaran kembali meningkat menjadi 100 persen.
Data diperoleh berdasarkan daftar aktivitas siswa yang tertera pada lembar observasi pada setiap pembelajaran menggunakan metode pembelajaran Socrates. Dari empat pertemuan, dapat disajikan dalam tabel 4.

\section{Tabel 4 Hasil Observasi Aktivitas Siswa}

\begin{tabular}{ccc}
\hline Pertemuan & Skor Total & Presentase (\%) \\
\hline 1 & 22 & 78,56 \\
2 & 25 & 89,29 \\
3 & 26 & 92,86 \\
4 & 28 & 100,00 \\
\hline
\end{tabular}

Berdasarkan tabel tersebut, persentase keaktifan siswa pada pertemuan pertama mencapai 78,56 persen. Persentase keaktifan siswa pada pertemuan keempat dan merupakan pertemuan terakhir proses pembelajaran meningkat menjadi 100 persen.
Hasil analisis deskriptif nilai tes kemampuan berpikir kreatif matematis siswa dengan menggunakan SPSS diperoleh data yang disajikan dalam bentuk tabel 4.5 .

Tabel 5. Deskripsi Statistik Data Pretes-Posttest Kemampuan Berpikir Kreatif Matematis Siswa

\begin{tabular}{lccc}
\hline & \multicolumn{2}{c}{ Statistics } \\
& & PRETEST & POSTTEST \\
\hline $\mathrm{N}$ & Valid & 34 & 34 \\
& Missing & 0 & 0 \\
Mean & 27,02 & 63,80 \\
Median & 26.30 & 62.90 \\
Mode & 36 & $37^{\mathrm{a}}$ \\
Std. Deviation & 13,053 & 17,176 \\
Variance & 170,389 & 295,003 \\
Minimum & 2 & 37 \\
Maximum & 53 & 94 \\
Sum & 919 & 2169 \\
\hline
\end{tabular}

Berdasarkan analisis deskripsi diperoleh selisih rata-rata pretest dan posttest $\left(\mu_{B}\right)$ sebesar 36,78 . Hal ini menunjukkan bahwa kemampuan berpikir kreatif matematis siswa lebih baik setelah diajar dengan menggunakan metode pembelajaran Socrates dibandingkan dengan sebelum diajar menggunakan metode pembelajaran Socrates.

Uji normalitas data dilakukan untuk mengetahui apakah selisih rata-rata pretest dan posttest kemampuan berpikir kretaif 
matematis siswa yang diperoleh pada kelas eksperimen berasal dari populasi yang berdistribusi normal atau tidak.

Hipotesis statistika yang digunakan.

$H_{0}$ : Sampel berasal dari populasi yang berdistribusi normal

$H_{1}$ : Sampel berasal dari populasi yang tidak berdistribusi normal

Kriteria pengambilan keputusan adalah jika Asymp. Sig. (2-tailed) $>\alpha=$
0,05 maka terima $H_{0}$ sehingga data berasal dari populasi yang berdistribusi normal. Jika Asymp. Sig. (2-tailed) $<\alpha=0,05$ maka tolak $H_{0}$ sehingga data berasal dari populasi yang tidak berdistribusi normal.

Adapun hasil uji normalitas data pretest dan posttest kemampuan berpikir kreatif matematis siswa dilakukan dengan menggunakan program SPSS dapat dilihat pada tabel 6 .

Tabel 6. Hasil Statistik Uji Normalitas Data Pretest-Posttest Kemampuan Berpikir Kreatif Matematis Siswa

One-Sample Kolmogorov-Smirnov Test

SELISIH

\begin{tabular}{llc}
\hline $\mathrm{N}$ & & 34 \\
Normal Parameters $^{a, b}$ & Mean & 36,79 \\
& Std. Deviation & 16,905 \\
& Absolute & 0,109 \\
Most Extreme Differences & Positive & 0,058 \\
& Negative & $-0,109$ \\
Kolmogorov-Smirnov $Z$ & & 0,634 \\
Asymp. Sig. (2-tailed) & & 0,817 \\
\hline
\end{tabular}

Pada tabel 6 dapat dilihat bahwa nilai Asymp. Sig. (2-tailed) selisih pretest dan posttest adalah $0,817>\alpha$ (dengan $\alpha=$ 0,05), sehingga $H_{0}$ diterima. Dengan demikian, dapat disimpulkan bahwa selisih rata-rata data pretest dan data posttest kemampuan berpikir kreatif matematis siswa berdistribusi normal. Setelah dilakukan uji normalitas, maka diperoleh data selisih rata-rata pretestposttest adalah berdistribusi normal. Dengan demikian, untuk menguji apakah ada pengaruh metode pembelajaran Socrates terhadap kemampuan berpikir kreatif matematis siswa digunakan uji-t satu sampel data berpasangan (paired sample t-test).

Adapun hipotesis statistik yang diuji dalam penelitian ini adalah.

$$
\mathrm{H}_{0}: \mu_{\mathrm{B}} \leq 0 \text { lawan } \mathrm{H}_{1}: \mu_{\mathrm{B}}>0
$$

Untuk menguji apakah ada pengaruh positif yang signifikan metode pembelajaran Socrates terhadap kemampuan berpikir kreatif matematis siswa. Berdasarkan hasil analisis uji-t dapat dilihat bahwa nilai sig.(2-tailed) selisish rata-rata posttest-pretest diperoleh 0,000. Perhitungan dengan menggunakan program SPSS dengan melihat nilai setengah dari sig. (2-tailed) $=1 / 2(0,000)=0,000<\alpha$ dengan $\alpha=$ 0,05 sehingga $\mathrm{H}_{0}$ ditolak. Dengan ditolaknya $\mathrm{H}_{0}$ maka dapat disimpulkan bahwa terdapat pengaruh positif yang signifikan metode pembelajaran Socrates terhadap kemampuan berpikir kreatif matematis siswa kelas VIII MTs Negeri 2 Bombana. 


\section{PEMBAHASAN}

Jenis penelitian ini adalah penelitian eksperimen dengan desain penelitian One Group Pretest PosttesT Design tentang pengaruh penerapan metode pembelajaran Socrates terhadap kemampuan berpikir kreatif matematis siswa pada materi Fungsi.Penelitian ini dilaksanakan di MTs Negeri 2 Bombana pada hari Kamis, 30Agustus 2018 sampai dengan Kamis, 20 September 2018.Penelitian ini menggunakan satu sampel yaitu kelas VIII $\mathrm{E}_{\mathrm{E}}$ sebagai kelas eksperimen yang diajar dengan menggunakan metode pembelajaran Socrates. Pada kelas eksperimen ini, siswa diberi pretest sebelum proses pembelajaran dilaksanakandengan materi Aljabar sebagai materi sebelumnya dan diberi posttest setelah proses pembelajaran dengan materi Fungsi. Sebelum pelaksanaan pretest peneliti mengingatkan kembali dan menjelaskan secara singkat pokok-pokok pembelajaran yang adapada materi Aljabar yang telah dipelajari sebelumnya. Setelah pengambilan data pretest kemudian dilaksanakan pembelajaran dengan menggunakan metode pembelajaran Socrates.Setelah dilaksanakan untuk kelas pembelajaran dengan menggunakan metode pembelajaran Socrates kemudian dilaksanakan posttest pada akhir pembelajaran.

Guru yang mengajar pada pelaksanaan penelitian dikelas eksperimen adalah peneliti sendiri dan dibantu oleh guru mata pelajaran untuk pengisian lembar observasi. Guru mata pelajaran yang membantu pada saat pengisian lembar observasi guru bernama Sitti Maemunah S.Si. Waktu pembelajaran pada penelitian ini adalah 10 jam pelajaran. Materi tes kemampuan berpikir kreatif matematis berbeda untuk pretest dan posttest.Untuk materipretest adalah Aljabar dan untuk materi posttest adalah Fungsi. Total pertemuan dalam penelitian ini adalah sebanyak enam kali pertemuan.
Empat kali pertemuan untuk proses pembelajaran, satu kali pertemuan untuk pretest dan satu kali pertemuan untuk posttest.

$\begin{array}{clr}\text { Metode } & \text { pembelajaran } & \text { yang } \\ \text { digunakan } & \text { adalah } & \text { metode }\end{array}$ pembelajaranyang dirancang oleh seorang tokoh filsafat Yunani bernama Socrates. Dalam metode pembelajaran Socrates siswa dihadapkan dengan sederet pertanyaan yang menuntut siswa berperan aktif didalam kelas melalui proses tanya jawab.

Deskripsi kemampuan berpikir kreatif matematis siswa diperoleh melalui tes kemampuan berpikir kreatif yang diawali dengan tahap persiapan instrument tes.Sebelum siswa diberi perlakuan berupa metode pembelajaran Socrates, terlebih dahulu siswa diberikan pretest dan setelah diberi perlakuan berupa metode pembelajaran Socrates maka dilakukan posttest.Soal-soal pretest-posttest yang digunakan terlebih dahulu diuji panelis dengan tujuan untuk mengetahui validitas dan reliabilitasnya.Selanjutnya diadakan pengolahan data untuk mengetahui soal yang memenuhi kriteria valid dan semua soal tersebut layak digunakan untuk pretest kemampuan berpikir kreatif matematis.Reliabilitas tes berada pada kategori tinggi.Untuk posttest diadakan pengolahan data berdasarkan hasil uji panelis untuk mengetahui soal yang memenuhi kriteria valid dan relieabel.Dari hasil perhitungan menunjukkan bahwa dari 5 soal yang diuji panelis semua soal memenuhi kriteria valid dan semua soal tersebut digunakan sebagai instrument posttest kemampuan berpikir kreatif matematis siswa.Reliabilitas tes berada pada kategori sangat tinggi.

Uji prasyarat terlebih dahulu dilakukan sebelum melakukan uji hipotesis. Uji prasyarat yang dilakukan yaitu uji normalitas data pada sampel. Berdasarkan uji normalitas data diperoleh data dari rata-rata selisih pretest- 
posttestkemampuan berpikir kreatif matematis siswa kelas VIII MTs Negeri 2 Bombana berdistribusi normal.

Pengujian hipotesis pada penelitian ini menggunakan uji-t data satu sampel (paired sample test), dengan terlebih dahulu melewati pengujian prasyarat yaitu uji normalitas terhadap data pretestposttest.Berdasarkan hasil uji normalitas, data berdistribusi normal. Maka tahap selanjutnya, melakukan uji hipotesis menggunakan rumus uji-t melalui aplikasi SPSS dengan melihat setengah dari sig. (2-tailed) lebih kecil dari 0,05 yang berarti $\mathrm{H}_{0}$ ditolak. Nilai sig. (2-tailed) yang diperoleh yaitu 0,000 maka setengah dari $0,000=0,000$ lebih kecil dari 0,05 sehingga $\mathrm{H}_{0}$ ditolak. Maka dapat disimpulkan bahwa pembelajaran matematika dengan menggunakan metode pembelajaran Socrates mempunya pengaruh yang signifikan terhadap kemampuan berpikir kreatif matematis siswa kelas VIII MTs Negeri 2 Bombana dan merujuk pada hasil analisis n-gain diperoleh 5 orang siswa berada pada kategori tinggi, 22 orang siswa berada pada kategori sedang, dan 7 orang siswa lainnya berada pada kategori rendah. Sehingga dapat dikatakan bahwa rata-rata peningkatan kemampuan berpikir kreatif matematis siswa berada pada kategori

\section{KESIMPULAN DAN SARAN}

Berdasarkan hasil penelitian dan pembahasan, maka diberikan kesimpulan sebagai berikut.

1. Persentasi keberhasilan guru pada pembelajaran dengan menggunakan metode pembelajaran Socrates terus meningka pada tiap pertemuan mencapai 100 persen. Adapun persentase keaktifan siswa dalam menerima pembelajaran pada pertemuan pertama hingga pertemuan sedang yang artinya metode pembelajaran Socrates dalam penelitian ini mempunyai pengaruh yang sedang terhadap kemampuan berpikir kreatif matematis siswa kelas VIII MTs Negeri 2 Bombana.

Penulis menyadari bahwa masih banyak kekurangan dalam penelitian ini sehingga menyebabkan rata-rata peningkatan kemampuan berpikir kreatif siswa berada pada kategori sedang.Salah satunya adalah keterbatasan waktu dalam mengelolah pembelajaran sehingga tidak menjamin ketercapaian pelaksanaan pembelajaran yang optimal serta keterbatasan dalam mengkondisikan kelas agar pelaksanaan pembelajaran berlangsung menyenangkan bagi siswa.Namun kenyataan yang diperoleh dalam penelitian ini yaitu terdapat pengaruh yang signifikan metode pembelajaran Socrates terhadap kemampuan berpikir kreatif matematis siswa.Terjadinya peningkatan kemampuan berpikir kreatif matematis ini disebabkan oleh penggunaan metode pembelajaran Socrates.Dimana, pembelajaran tersebut menuntut siswa untuk berperan aktif dalam mengembangkan pemikirannya melalui sederetan pertanyaan yang diharapkan mereka menemukan jawaban berdasarkan pemikiran mereka sendiri.

keempat juga mengalami peningkatan mencapai 100 persen.

2. Kemampuan berpikir kreatif matematis siswa sebelum diajar dengan menggunakan metode pembelajaran Socrates diperoleh nilai rata-rata sebesar 27,02 sedangkan nilai rata-rata kemampuan berpikir kreatif matematis siswa setelah diajar menggunakan metode pembelajaran Socrates sebesar 63,80. Median untuk pretest sebesar 26,30 dan untuk 
posttest sebesar 62,90. Modus untuk pretest yaitu 36 dan posttest 37. Standar deviasi (simpangan baku) sebesar 13,053 untuk pretest dan 17,176 untuk posttest. Nilai minimum kemampuan berpikir kreatif matematis siswa pada saat pretest sebesar 2 dan nilai maksimumnya sebesar 53, sedangkan nilai minimum pada saat pretest adalah 37 dan nilai maksimumnya sebesar 94.

3. Berdasarkan pengujian hipotesis dapat disimpulkan bahwa terdapat pengaruh positif yang signifikan metode pembelajaran Socrates terhadap kemampuan berpikir kreatif matematis siswa kelas VIII MTs Negeri 2 Bombana. Hal ini berdasarkan pada nilai sig. $(2$-tailed $)=$ $1 / 2(0,000)=0,000$ lebih kecil dari nilai $\alpha=0,05$ sehingga $\mathrm{H}_{0}$ ditolak. Hasil tersebut menunjukkan bahwa

\section{DAFTAR PUSTAKA}

Bandi, N. T. L. 2016. Pengaruh Model Pembelajaran Berbasis Masalah Terhadap Hasil Belajar Matematika Siswa Kelas VIII SMP Negeri 12 Kendari. Skripsi Universitas Halu Oleo: Tidak Diterbitkan.

Hidayat. 2011. Meningkatkan Kemampuan Berpikir Kreatif Matematik Siswa Sekolah Menengah Atas Melalui Pembelajaran Kooperatif ThinkTalk-Write (TTW). Prosiding Seminar Nasional Pendidikan Matematika STKIP Siliwangi Bandung. 1: 272-279.

Johnson, D.W. \& Johnson, R.T. 2002. Meaningful Assessment. Boston: Allyn \& Bacon.

Khodijah, Nyayu. 2006. Psikologi Belajar. Palembang: IAIN Raden Fatah Press

Laksmi, N. 2016. Pengaruh Penerapan Model Pembelajaran Problem Based Learning (PBL) Terhadap kemampuan berpikir kreatif matematis siswa kelas VIII MTs Negeri 2 Bombana mengalami peningkatan setelah diajar dengan Metode Pembelajaran Socrates.

Saran yang dapat diberikan dari hasil penelitian ini yaitu:

1. Kepada guru yang mengajar sekiranya dapat menggunakan metode pembelajaran Socrates sebagai salah satu alternatif dalam pembelajaran matematika untuk mengasah kemampuan berpikir kreatif matematis siswadalam pembelajaran.

2. Hendaknya kemampuan berpikir kreatif matematis siswa mendapat perhatian yang lebih serius oleh guru untuk meningkatkan penguasaan materi serta kemampuan penyelesaian masalah yang dimiliki siswa.

Hasil Belajar Matematika Siswa (Studi Eksperimen pada Siswa Kelas VII SMP Negeri 10 Kendari). Skripsi Universitas Halu Oleo: Tidak Diterbitkan.

Lestari, K. E. dan Yudhanegara, M. R. 2017. Penelitian Pendidikan Matematika. Bandung: PT Refika Aditama.

Pahlavi, R.S. 2014. Pengaruh Metode Socrates dalam Pembelajaran Bangun Datar terhadap Kemampuan Berpikir Kritis Siswa kelas VII SMP Kristen Satya Wacana. Skripsi. Salatiga: Universitas Kristen Satya Wacana.

Sudjana. 2005. Metoda Statistika. Bandung: Tarsito. 